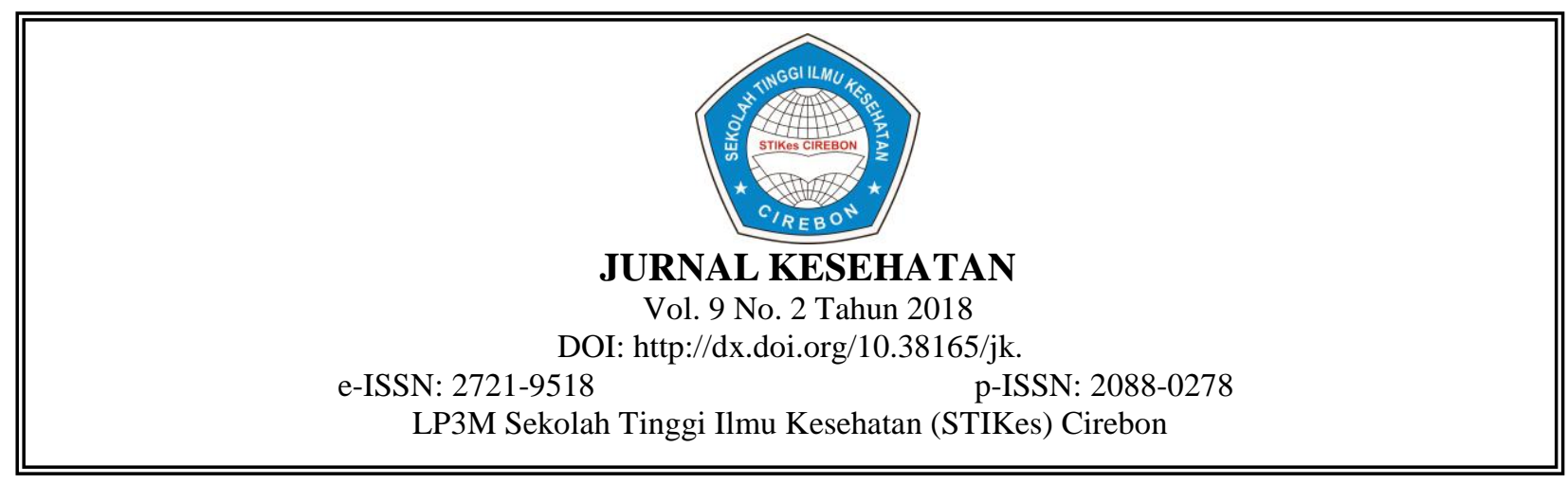

\title{
HUBUNGAN KARAKTERISTIK INDIVIDU DENGAN TINGKAT DISIPLIN KERJA
}

Muslimin*
Program Studi Kesehatan Masyarakat, Sekolah Tinggi Ilmu Kesehatan Cirebon
mistermuslimin@gmail.com

\begin{abstract}
Abstrak
Kedisiplinan merupakan keinginan dan kesadaran untuk mentaati peraturan-peraturan perusahaan dan norma-norma sosial. Seseorang akan bersedia mematuhi semua peraturan serat melaksanakan tugas-tugasnya, baik secara sukarela maupun karena terpaksa. Disiplin kerja juga mempunyai kontribusi terhadap kualitas pelayanan kesehatan yang pada akhirnya berdampak pada produktivitas kerja. Tujuan dari penelitian ini adalah menganalisis hubungan antara karakteristik individu dengan tingkat disiplin kerja di Rumah Sakit PTPN VIII Subang Tahun 2018. Desain penelitian dengan metode deskripsi korelasi dengan pendekatan cross sectional, populasi dan sampel adalah seluruh karyawan non kesehatan. Sampel berjumlah 23 orang, yang diambil menggunakan teknik total samplin. Pengumpulan data dengan menggunakan kuesioner dan lembar observasi dan penelitian di laksanakan bulan September sampai November 2018. Analisis data dengan uji chi square. Hasil penelitian ini menunjukkan sebagian Karyawan Rumah Sakit PTPN VIII Subang berumur $25-45$ tahun, lebih dari setengahnya berjenis kelamin laki-laki, lebih dari setengahnya berpendidikan rendah, sebagian besar berstatus kawin. Lebih dari setengah Karyawan memiliki lama kerja 5 tahun. Disiplin kerja Karyawan Rumah Sakit PTPN VIII Subang lebih dari setengahnya mempunyai disiplin yang baik.
\end{abstract}

Kata Kunci: Karakteristik individu, Disiplin kerja

\begin{abstract}
Discipline is the desire and awareness to obey company rules and social norms. Someone will be willing to comply with all regulations fiber to perform his duties, either voluntarily or by necessity. Labor discipline also contributes to the quality of care services, which in turn have an impact on work productivity. The purpose of this study was to analyze the relationship between individual characteristics with the level of labor discipline in PTPN VIII Subang Hospital. Description of the study design with the method of correlation with cross -sectional sample of the population and all employees. The sample was 23 people, and in this study the sample used is to use the total sampling techniques. Data collection using questionnaires and observation sheets and research carried onSeptember to November, 2018. Data analysis with chi square test.The results of the research staff of the PTPN VIII Subang Hospital half old 25-45 years old, more than half of the male sex, more than half of low-educated, largely 's marital status. More than half of employees have a 5 year old job. Discipline PTPN VIII Subang Hospital Employees working more than half have good discipline.
\end{abstract}

Keywords: Individual characteristics, Work discipline 


\section{PENDAHULUAN}

Terbukanya pasar bebas berakibat tingginya kompetisi di sektor kesehatan dan kompleksnya permasalahan sehingga unit-unit pelayanan kesehatan berlomba-lomba untuk meningkatkan kualitas pelayanan dan produktivitasnya. Pengaruh terbesar akibat era globalisasi tersebut adalah perkembangan pelayanan kesehatan. Persaingan antar pemberi pelayanan baik pemerintah, swasta dan asing akan semakin ketat. Selain itu, masyarakat menuntut unit pelayanan kesehatan dapat memberikan pelayanan secara mudah cepat, akurat, bermutu dan dengan biaya terjangkau. ${ }^{1}$

One Steep Quality Service merupakan alternatif untuk menjawab tuntutan masyarakat terhadap pelayanan kesehatan di mana pelayanan kebutuhan pasien tidak dapat dirasakan dengan baik dan pasien merasakan kurang puas dan menganggap bahwa profesionalisme dan mutu pelayanan masih rendah. Tuntutan masyarakat akan terpenuhi jika pemberi layanan memiliki profesionalisme yang tinggi dan mampu mempertahankan citra dan kinerja yang memenuhi standar pelayanan. ${ }^{1}$ Pelayanan yang berkualitas adalah pelayanan yang dapat memuaskan setiap pemakai jasa pelayanan kesehatan sesuai dengan tingkat kepuasan serta penyelenggaraannya sesuai dengan standar dan kode etik profesi yang telah ditetapkan, ${ }^{2}$ begitu juga dengan pelayanan yang diberikan di rumah sakit.

Rumah sakit merupakan suatu organisasi dengan core bussineesnya sebagai penyedia jasa pelayanan kesehatan. Tujuannya antara lain memberikan pelayanan kesehatan secara profesional dan berkualitas kepada para pelanggan. Untuk mencapai tujuan tersebut perlu adanya dukungan dari berbagai pihak antara lain struktur organisasi, perilaku kelompok dan prilaku individu/perorangan. ${ }^{3}$

Organisasi pelayanan kesehatan harus membenahi semua aspek yang berhubungan dengan peningkatan kualitas pelayanan yang diberikan termasuk pembenahan terhadap sumberdaya manusianya. Selain itu kualitas pelayanan kesehatan yang dihasilkan oleh rumah sakit sangat dipengaruhi oleh kinerja pemberi pelayanan kesehatan itu sendiri, terbentuknya kinerja yang baik dapat terlihat dengan hasil kerjanya dan kedisiplinan para karyawannya sehingga akan dapat meningkatkan motivasi serta produktivitas yang dapat berpengaruh terhadap laju roda organisasi. Namun pada kenyataannya tidaklah mudah membentuk kinerja dan kedisiplinan para karyawannya. Terdapat faktor yang mempengaruhi kualitas pelayanan kesehatan di institusi pelayanan kesehatan diantaranya keterbatasan sumber daya manusia (SDM) baik dari segi jumlah, juga masih terbatasnya SDM yang menerapkan nilai-nilai moral dan etika profesi. ${ }^{1}$ Permasalahan yang sering terjadi saat. ini adalah, banyaknya keluhan masyarakat akan pelayanan kesehatan. Kondisi ini menunjukkan banyaknya masalah di institusi pelayanan kesehatan termasuk di puskesmas, rumah sakit, klinik kesehatan dan balai pengobatan kesehatan yang harus dibenahi, terutama pada aspek sumber daya manusianya.

Kurangnya nilai-nilai moral dan etika sumberdaya manusia akan berdampak terhadap disiplin kerjanya. Berdasarkan hasil observasi yang dilakukan pada tanggal 18-19 Nopember 2018 . (selama dua hari) di Rumah Sakit PTPN VIII Subang diperoleh hasil bahwa dari 23 pegawai terdapat 14 orang pegawai yang datang terlambat dan 9 orang yang datang tepat waktu. Sebagian besar yang terlambat adalah perempuan (11 orang), dengan alasan melakukan pekerjaan sebagai isteri terlebih dahulu, yaitu menyiapkan sarapan untuk suami, memandikan anak dan lain-lain, padahal kewajiban sebagai seorang pegawai adalah mentaati peraturan dan tata tertib pegawai, termasuk jam datang maupun jam pulang sebagai salah satu indikator dari tingkat kedisiplinan kerja.

Kedisiplinan merupakan keinginan dan kesadaran untuk mentaati peraturan-peraturan perusahaan dan norma-norma sosial. Seseorang akan bersedia mematuhi semua peraturan serta melaksanakan tugas-tugasnya, baik secara sukarela maupun karena terpaksa. ${ }^{4}$ Kedisiplinan dapat diartikan, jika karyawan selalu datang dan pulang tepat waktunya, melakukan pekerjaan yang menjadi tugasnya dengan baik, mematuhi segala peraturan organisasi dan norma-norma sosial yang berlaku.

Disiplin kerja juga mempunyai kontribusi terhadap kualitas pelayanan kesehatan yang pada akhirnya berdampak pada produktivitas kerjanya. ${ }^{2}$ Tanpa ada dukungan disiplin yang tinggi dari 
pegawai, perusahaan atau organisasi sulit untuk mewujudkan tujuan yang ingin dicapai. Terdapat beberapa faktor yang mempengaruhi tingkat kedisiplinan pegawai suatu organisasi (puskesmas atau rumah sakit), di antaranya yaitu tujuan dan kemampuan, kepuasan kerja, teladan pimpinan, balas jasa, keadilan, sanksi hukum, ketegasan dan hubungan kemanusiaan. ${ }^{4}$

Perilaku disiplin yang ditunjukkan oleh karyawan dapat menguntungkan organisasi khususnya yang berorientasi kepada produk jasa pelayanan yang dihasilkan. ${ }^{5}$ Variabel yang mempengaruhi perilaku dan prestasi ${ }^{6}$ yaitu (1) variabel individu yang terdiri dari kemampuan dan keterampilan (mental, fisik, dan latar belakang keluarga, tingkat sosial, pengalaman), demografi (umur asai usul jenis kelamin), dan (2) variabel organisasi yang terdiri dari sumber daya, kepemimpinan, imbalan. struktur dan desain pekerjaan, serta (3) variabel psikologi yang terdiri dari persepsi, sikap, kepribadian, belajar, motivasi.

Jenis kelamin laki-laki dan perempuan secara konsisten tidak ada perbedaan antara kinerja laki-laki dan perempuan dalam kemampuan memecahkan masalah, keterampilan analisis, dorongan kompetisi, motivasi dan kemampuan belajar. Beberapa riset mengenai tingkat ketidakhadiran mengatakan bahwa perempuan lebih tinggi daripada laki-laki. Hal ini ada kaitannya dengan peran perempuan dalam tanggung jawab keluarga dan perawatan anak serta sebagai pencari nafkah sekunder. ${ }^{7}$

Latar belakang pendidikan akan mempengaruhi motivasi kerja yang akhirnya berdampak pada tingkat disiplin kerja individu, Semakin tinggi tingkat pendidikan maka akan meningkatkan kemampuan dan keterampilan para pegawai dan mendapatkan promosi jabatan tertentu yang pada gilirannya dapat meningkatkan produktivitas organisasi. ${ }^{8,9}$

Lama kerja berpengaruh terhadap pengalaman dan keterampilan seseorang dalam melaksanakan pekerjaannya. Pegawai yang telah berpengalaman akan lebih siap dan mampu menyelesaikan pekerjaannya dibandingkan dengan yang belum berpengalaman. Sehingga dapat diasumsikan bahwa kerja individu dalam suatu profesi akan semakin meningkatkan kinerjanya termasuk disiplin kerjanya. ${ }^{4,7,8}$

Status perkawinan berpengaruh terhadap perilaku seseorang dalam kehidupan organisasinya, baik secara positif maupun negatif, pegawai yang sudah menikah lebih sedikit absensinya, mengalami turn over yang lebih rendah dan lebih mengekspresikan perasaan puas terhadap pekerjaannya daripada yang belum menikah. ${ }^{8}$ Hal ini disebabkan karena adanya tanggung jawab terhadap pemenuhan kebutuhan ekonomi keluarga.

Berdasarkan hasil observasi yang dilakukan pada tanggal 18-19 Nopember 2018 (selama dua hari) di Rumah Sakit PTPN VIII Subang sebagian besar yang mengalami keterlambatan dalam kehadiran kerja adalah berjenis perempuan yaitu 11 orang, sudah menikah 9 orang, dan usianya antara 25-35 tahun. Jumlah tenaga keseluruhan di Rumah Sakit PTPN VIII Subang yaitu sebanyak 101 orang dan pegawai non kesehatan berjumlah 23 orang dengan status pendidikan yang bervariasi, namun rata-rata pendidikan S1 (Strata 1) $(75 \%)$, dan pengalaman kerja lebih dari setengahnya antara 5-10 tahun (60\%). Tujuan penelitian ini untuk mengetahui hubungan karakteristik individu pegawai dengan tingkat disiplin kerja di Rumah Sakit PTPN VIII Subang Tahun 2018.

\section{METODE PENELITIAN}

Penelitian ini merupakan penelitian deskriptif korelasi dengan pendekatan cross sectional untuk melihat hubungan karakteristik individu pegawai dengan tingkat disiplin kerja pegawai di Rumah Sakit PTPN VIII Subang Tahun 2018. Populasi adalah seluruh pegawai non kesehatan Rumah Sakit PTPN VIII Subang Tahun 2018 yang berjumlah 23 orang. Sampel dalam penelitian ini diambil dengan menggunakan teknik total sampling. Teknik pengumpulan data menggunakan kuesioner dan lembar observasi. Instrumen penelitian terdiri dari dua bagian yaitu kuesioner A tentang karakteristik individu dan kuesioner B tentang disiplin kerja pegawai. Analisa untuk menguji hubungan dari tiap-tiap variabel independent dan dependent menggunakan uji statistik chi square dengan tingkat kepercayaan 95\% (alpha 0,05). 


\section{HASIL PENELITIAN}

Karakteristik individu dalam penelitian ini meliputi umur, jenis, kelamin, pendidikan, status perkawinan dan masa kerja.

\section{Karakteristik Individu Pegawai}

Tabel 1. Distribusi frekuensi karakteristik individu pegawai Rumah Sakit PTPN VIII Subang Tahun 2018

\begin{tabular}{ccc}
\hline Variabel Karakteristik Individu & F & Persentase (\%) \\
\hline Umur & 6 & \\
$<25$ tahun & 14 & 26,1 \\
$25-45$ tahun & 3 & 60,9 \\
$>45$ tahun & 11 & 13,0 \\
\hline Jenis kelamin & 12 & 47,8 \\
Perempuan & & 52,2 \\
Laki - laki & 12 & \\
Pendidikan & 11 & 52,2 \\
Rendah & & 47,8 \\
Tinggi & 17 & 73,9 \\
Status Perkawinan & 6 & 26,1 \\
Kawin & & \\
Tidak kawin & 10 & 43,5 \\
Lama Kerja & 13 & 56,5 \\
< 5 tahun &
\end{tabular}

Berdasarkan tabel 1 menunjukkan bahwa sebagian besar $(60,9 \%)$ umur karyawan rumah Sakit PTPN VIII Subang adalah berumur 25 - 45 tahun, berjenis kelamin laki-laki $(52,2 \%)$ serta berpendidikan rendah $(52,2 \%)$. Sedangkan untuk status perkawinan sebagian besar adalah kawin $(73,9 \%)$ dan lebih dari setengahnya mempunyai masa kerja lebih dari 5 tahun $(56,5 \%)$.

\section{Disiplin Kerja}

Tabel 2. Distribusi Frekuensi Disiplin Kerja Karyawan Rumah Sakit PTPN VIII Subang Tahun 2018

\begin{tabular}{ccc}
\hline Variabel Disiplin Kerja & F & Persentase (\%) \\
\hline 1. Disiplin Baik & 13 & 56,5 \\
2. Disiplin kurang & 10 & 43,5 \\
\hline Total & 23 & 100
\end{tabular}

Berdasarkan tabel 2 menunjukkan bahwa lebih dari setengah karyawan Rumah Sakit PTPN VIII Subang mempunyai tingkat disiplin yang baik sebesar $56,5 \%$.

\section{Hubungan Antara Umur Dengan Tingkat Disiplin Kerja Karyawan Rumah Sakit PTPN VIII Subang}

Tabel 3. Tabulasi silang Hubungan Umur dengan Tingkat Disiplin Kerja Karyawan Rumah Sakit PTPN VIII Subang 2018

\begin{tabular}{|c|c|c|c|c|c|c|}
\hline \multirow{3}{*}{ Sub Variabel umur } & \multicolumn{5}{|c|}{ Tingkat Disiplin } & \multirow{3}{*}{$P$ Value } \\
\hline & \multicolumn{2}{|c|}{ kurang } & \multicolumn{2}{|c|}{ baik } & \multirow{2}{*}{ total } & \\
\hline & $\mathrm{n}$ & $\%$ & $\mathrm{n}$ & $\%$ & & \\
\hline$<25$ Tahun & 5 & 83,3 & 1 & 16,7 & 6 & \multirow{3}{*}{0,026} \\
\hline $25-45$ tahun & 3 & 21,4 & 11 & 78,6 & 14 & \\
\hline$>45$ tahun & 2 & 66,7 & 1 & 33,3 & 3 & \\
\hline
\end{tabular}




\begin{tabular}{llllll}
\hline Jumlah & 10 & 43,4 & 13 & 56,6 & 23 \\
\hline
\end{tabular}

Berdasarkan hasil penelitian pada tabel 3 diperoleh hasil bahwa tingkat disiplin karyawan Rumah Sakit PTPN VIII Subang pada umur antara 25- 45 tahun adalah baik $(78,6 \%)$. Hasil uji statistik dengan chi square diperoleh $p$ value $=0,026$ dengan alpha 0,05 berarti ada hubungan yang signifikan antara usia responden dengan tingkat disiplin kerja di Rumah Sakit PTPN VIII Subang.

\section{Hubungan Antara Jenis Kelamin Dengan Tingkat Disiplin Kerja Karyawan Rumah Sakit PTPN VIII Subang}

Tabel 4. Distribusi Frekuensi Hubungan jenis kelamin dengan Tingkat Disiplin Kerja Karyawan rumah Sakit PTPN VIII Subang 2018

\begin{tabular}{ccccccc}
\hline & \multicolumn{7}{c}{ Tingkat Disiplin } \\
\hline \multirow{2}{*}{$\begin{array}{c}\text { Sub Variabel Jenis } \\
\text { Kelamin }\end{array}$} & \multicolumn{2}{c}{ kurang } & \multicolumn{2}{c}{ baik } & \multirow{2}{*}{ total } & \multirow{2}{*}{ P Value } \\
\cline { 2 - 6 } & $\mathrm{n}$ & $\%$ & $\mathrm{n}$ & $\%$ & \multirow{2}{*}{0,012} \\
\hline Perempuan & 8 & 72,7 & 3 & 17,3 & 11 \\
\hline Laki-laki & 2 & 16,7 & 10 & 83,3 & 12 \\
\hline Jumlah & 10 & 43,4 & 13 & 56,6 & 23 & \\
\hline
\end{tabular}

Berdasarkan hasil penelitian pada tabel 4 diperoleh hasil bahwa terdapat 8 responden $(72,2 \%)$ berjenis kelamin perempuan yang mempunyai tingkat disiplin kerja yang kurang dan hanya terdapat 3 responden $(17,3 \%)$ berjenis kelamin perempuan yang mempunyai tingkat disiplin kerja yang baik. Pada jenis kelamin laki-laki yang mempunyai tingkat disiplin kerja yang kurang. Hasil uji statistik dengan chi square diperoleh $\mathrm{p}$ value $=0,012$ dengan alpha 0,05 , berarti ada hubungan yang signifikan antara jenis kelamin responden dengan tingkat disiplin kerja di Rumah Sakit PTPN VIII Subang

\section{Hubungan Antara Pendidikan Dengan Tingkat Disiplin Kerja Karyawan Rumah Sakit PTPN VIII Subang}

Tabel 5. Distribusi frekuensi hubungan pendidikan dengan tingkat disiplin kerja karyawan Rumah Sakit PTPN VIII Subang Tahun 2018

\begin{tabular}{ccccccc}
\hline \multicolumn{7}{c}{ Tingkat Disiplin } \\
\hline \multirow{2}{*}{$\begin{array}{c}\text { Sub Variabel } \\
\text { Pendidikan }\end{array}$} & $\mathrm{n}$ & $\%$ & $\mathrm{n}$ & $\%$ & \multirow{2}{*}{ total } & \multirow{2}{*}{ P Value } \\
\cline { 2 - 6 } & 8 & 66,7 & 4 & 33,3 & 13 & \multirow{2}{*}{0,036} \\
\hline Rendah & 2 & 18,2 & 9 & 81,8 & 11 \\
\hline Tinggi & 10 & 43,4 & 13 & 56,6 & 23 & \\
\hline Jumlah & & & & & &
\end{tabular}

Berdasarkan hasil penelitian pada tabel 5 diperoleh hasil bahwa terdapat 8 responden $(66,7 \%)$ berpendidikan rendah mempunyai tingkat disiplin kerja yang kurang dan terdapat 4 responden $(33,3 \%)$ berjenis berpendidikan rendah yang mempunyai tingkat disiplin kerja yang baik. Pada tingkat pendidikan yang tinggi terdapat 9 respon $(81,8 \%)$ mempunyai tingkat disiplin kerja yang baik dan terdapat 2 responden $(18,2 \%)$ yang berpendidikan tinggi yang mempunyai tingkat disiplin kerja yang kurang. Hasil uji statistik dengan chi square diperoleh $p$ value $=0,036$ dan alpha 0,05 berarti ada hubungan yang signifikan antara pendidikan responden dengan tingkat disiplin kerja di Rumah Sakit PTPN VIII Subang Tahun 2018.

\section{Hubungan Antara Status Perkawinan Dengan Tingkat Disiplin Kerja Karyawan Rumah Sakit PTPN VIII Subang}


Tabel 6. Distribusi Frekuensi Hubungan status Perkawinan dengan Tingkat Disiplin kerja karyawan Rumah Sakit PTPN VIII Subang 2018

\begin{tabular}{ccccccc}
\hline \multirow{2}{*}{$\begin{array}{c}\text { Sub Variabel } \\
\text { Perkawinan }\end{array}$} & \multicolumn{9}{c}{ Tingkat Disiplin } \\
\cline { 2 - 6 } & \multicolumn{2}{c}{ kurang } & baik & \multirow{2}{*}{ total } & \multirow{2}{*}{ P Value } \\
\cline { 2 - 6 } & $\mathrm{n}$ & $\%$ & $\mathrm{n}$ & $\%$ & 17 \\
\hline Kawin & 10 & 58,8 & 7 & 41,2 & \multirow{2}{*}{0,019} \\
\hline Tidak kawin & 0 & 0 & 6 & 100 & 6 \\
\hline Jumlah & 10 & 43,4 & 13 & 56,6 & 23 & \\
\hline
\end{tabular}

Berdasarkan hasil penelitian pada tabel 6 diperoleh hasil bahwa terdapat 10 responden $(58,8 \%)$ berstatus kawin mempunyai tingkat disiplin kerja yang kurang dan terdapat 7 responden $(41,2 \%)$ berstatus kawin yang mempunyai tingkat disiplin kerja yang baik. Serta seluruh responden (6 responden) yang berstatus tidak kawin mempunyai tingkat disiplin kerja yang baik. Hasil uji statistik dengan chi square diperoleh $p$ value $=0,019$ dan alpha 0,05 berarti ada hubungan yang signifikan antara status perkawinan responden dengan tingkat disiplin kerja di Rumah Sakit PTPN VIII Subang

\section{Hubungan antara lama kerja dengan tingkat disiplin kerja karyawan Rumah Sakit PTPN VIII Subang}

Tabel 7. Distribusi Frekuensi Hubungan status Perkawinan dengan Tingkat Disiplin kerja karyawan Rumah Sakit PTPN VIII Subang 2018

\begin{tabular}{ccccccc}
\hline & \multicolumn{7}{c}{ Tingkat Disiplin } \\
\hline \multirow{2}{*}{$\begin{array}{c}\text { Sub Variabel Lama } \\
\text { Kerja }\end{array}$} & \multicolumn{2}{c}{ kurang } & \multicolumn{2}{c}{ baik } & \multirow{2}{*}{ total } & \multirow{2}{*}{ P Value } \\
\cline { 2 - 6 } & $\mathrm{n}$ & $\%$ & $\mathrm{n}$ & $\%$ & \\
\hline$<5$ tahun & 8 & 80,0 & 2 & 20,0 & 10 \\
\hline$\geq 5$ tahun & 2 & 15,4 & 11 & 84,6 & 13 & \multirow{2}{*}{0,003} \\
\hline Jumlah & 10 & 43,4 & 13 & 56,6 & 23 & \\
\hline
\end{tabular}

Berdasarkan hasil penelitian pada tabel di atas diperoleh hasil bahwa terdapat 10 responden yang mempunyai lama kerja kurang dari 5 tahun dan 80,0\% mempunyai tingkat disiplin kerja yang kurang dan terdapat 13 responden yang memiliki lama kerja lebih dari 5 tahun yang mempunyai tingkat disiplin kerja yang baik. Hasil uji statistik dengan chi square diperoleh $p$ value $=0,003$, alpha 0,05 berarti ada hubungan yang signifikan antara masa kerja responden dengan tingkat disiplin kerja di Rumah Sakit PTPN VIII Subang

\section{PEMBAHASAN PENELITIAN Karakteristik Individu}

Berdasarkan hasil uji univariat pada karakteristik individu menunjukkan bahwa sebagian besar umur karyawan berumur 25 - 45 tahun sebesar 60,9\%, hal ini tergolong dengan usia yang masih produktif. Pada rentang usia ini juga menunjukkan tingkat kedewasaan psikologi, dimana semakin lanjut usia seseorang yang bersangkutan diharapkan semakin mampu menunjukkan kematangan jiwa, dalam arti semakin bijaksana, semakin mampu berpikir secara rasional, semakin mampu mengendalikan emosi, semakin toleran terhadap pandangan dan perilaku yang berbeda dari pandangan dan perilaku sendiri, dan sifat-sifat lain yang menunjukkan kematangan intelektual. ${ }^{8}$

Hasil penelitian ini juga didapatkan sebagian besar jenis kelamin karyawan Rumah Sakit PTPN VIII Subang adalah laki-laki sebesar 52,2\% Jenis kelamin laki-laki lebih sedikit tingkat kemangkirannya jika dibandingkan dengan perempuan, ${ }^{7}$ sehingga di rumah sakit banyaknya karyawan laki-laki akan mendukung program-program pelayanan di rumah sakit.

Hasil penelitian ini juga menunjukkan bahwa sebagian besar status perkawinan karyawan Rumah Sakit PTPN VIII Subang adalah kawin sebesar 73,9\%. Perkawinan dapat berdampak 
terhadap rasa tanggung jawab yang besar untuk menghidupi keluarganya, demikian juga dengan keinginan pindah kerja, karena dengan mencari lapangan kerja yang baru mengandung resiko yang lebih besar dibandingkan dengan tempat kerja sebelumnya. Ada korelasi positif antara status perkawinan dengan produktivitas kerjanya. ${ }^{8}$

Berdasarkan hasil penelitian ini sebagian besar karyawan mempunyai lama kerja $\geq 5$ tahun (56,5\%). Lama kerja juga berpengaruh terhadap pengalaman dan keterampilan dalam melakukan pekerjaannya. Karyawan yang telah berpengalaman dibandingkan yang belum berpengalaman, dengan demikian bahwa lama kerja individu dalam suatu profesi akan semakin meningkatkan kinerja dan produktivitasnya. $7,10,11$

\section{Disiplin Kerja}

Hasil penelitian menunjukkan bahwa sebagian besar disiplin kerja karyawan Rumah Sakit PTPN VIII Subang adalah baik sebesar 56,5\%. Disiplin kerja merupakan kegiatan yang dilaksanakan untuk mendorong para karyawan, agar mengikuti berbagai standar dan aturan, sehingga penyelewengan-penyelewengan dapat dicegah. Sasaran pokoknya adalah untuk mendorong disiplin diri, diantara para karyawan. ${ }^{12}$

\section{Hubungan antara Umur dengan Tingkat Disiplin Kerja Karyawan Rumah Sakit PTPN VIII Subang}

Berdasarkan hasil uji univariat terdapat $60,9 \%$ yang berusia antara 25 - 45 tahun dan terdapat 6 responden $(26,1 \%)$ berusia kurang dari 25 tahun, serta terdapat 13,0\% responden berusia lebih dari 45 tahun. Hasil uji bivariat tingkat disiplin karyawan Rumah Sakit PTPN VIII Subang pada umur antara 25 - 45 tahun adalah baik (78,6\%). Hasil uji statistik dengan chi square diperoleh $p$ value $=0,026$ dapa alpha 0,05 maka dapat disimpulkan bahwa hipotesis : ada hubungan yang signifikan antara usia responden dengan tingkat disiplin kerja karyawan Rumah Sakit PTPN VIII Subang tahun 2018 gagal ditolak.

Hasil penelitian ini sesuai dengan pendapat bahwa variabel yang mempengaruhi perilaku dan prestasi yaitu variabel individu yang terdiri dari kemampuan dan keterampilan (mental, fisik, dan latar belakang keluarga, tingkat sosial, pengalaman), demografi (umur, asal usul, jenis kelamin. ${ }^{10}$ Umur karyawan mempunya kaitan erat dengan berbagai kehidupan organisasi.

Umur berkaitan dengan tingkat kedewasaan seseorang baik kedewasaan teknis yaitu keterampilan melaksanakan tugas maupun kedewasaan secara psikologi. Dikaitkan dengan tingkat kedewasaan teknis, maka makin lama orang berkarya, kedewasaan teknisnya semakin meningkat. Dengan demikian juga tingkat kedewasaan psikologi, semakin lanjut usia seseorang yang bersangkutan diharapkan semakin mampu menunjukkan kematangan jiwa, dalam arti semakin bijaksana, semakin mampu berpikir secara rasional; semakin mampu mengendalikan emosi, semakin toleran terhadap pandangan dan perilaku yang berbeda dari pandangan dan perilaku sendiri, dan sifat-sifat lain yang menunjukkan kematangan intelektual. ${ }^{8}$

\section{Hubungan antara Jenis Kelamin dengan Tingkat Disiplin Kerja Karyawan Rumah Sakit PTPN VIII Subang}

Hasil penelitian menunjukkan bahwa dari 23 responden terdapat 11 responden $(47,8 \%)$ berjenis kelamin dan terdapat 12 responden $(52,2 \%)$ berjenis kelamin laki-laki. Hasil uji statistik dengan cih square diperoleh $p$ value $=0,012$ dengan alpha 0,05 maka hipotesis ada hubungan yang signifikan antara jenis kelamin responden dengan tingkat disiplin kerja karyawan Rumah Sakit PTPN VIII Subang 2018 gagal ditolak.

Hasil penelitian ini kecenderungan karyawan yang berjenis kelamin perempuan lebih banyak yang kurang disiplin dari pada laki-laki. Hal ini sesuai dengan hasil penelitian sebelumnya bahwa karyawan perempuan lebih banyak mangkir bekerja di bandingkan laki-laki, walaupun lebih lanjut ia mengemukakan dalam produktivitas kerja proporsi perempuan dalam keperawatan lebih banyak dibandingkan laki-laki, sehingga mungkin terjadi perbedaan dalam absensi dan turn over 
pada karyawan perempuan. ${ }^{7}$ Hal ini karena ada perbedaan karakter fungsi. Perempuan masih memiliki peran ganda, yaitu mengatur urusan rumah tangga di samping ia harus bekerja. ${ }^{1}$

\section{Hubungan antara Pendidikan dengan Tingkat Disiplin Kerja Karyawan Rumah Sakit PTPN VIII Subang}

Tingkat pendidikan responden berdasarkan hasil diperoleh hasil bahwa terdapat 52,2\% (12 responden) berpendidikan rendah dan terdapat 11 responden $(47,8 \%)$ berpendidikan tinggi. Hasil statistik dengan chi square diperoleh p value $=0,036$ dapa alpha 0,05 maka dapat disimpulkan bahwa hipotesisi : ada hubungan yang signifikan antara pendidikan responden dengan tingkat disiplin kerja karyawan Rumah Sakit PTPN VIII Subang tahun 2018 gagal ditolak.

Hasil penelitian ini sesuai dengan pendapat yang menyatakan bahwa pendidikan secara umum adalah segala upaya yang direncanakan untuk mempengaruhi orang lain baik individu, kelompok atau masyarakat sehingga mereka melakukan tindakan sesuai dengan yang diharapkan. ${ }^{9}$,

13 Tingkat pendidikan mempengaruhi kemampuan seseorang untuk mendengar, menyerap informasi, menyelesaikan masalah, dan sistem nilai, perilaku serta gaya hidup. ${ }^{14}$

Hasil penelitian ini juga sesuai dengan pendapat yang menyatakan bahwa tingkat pendidikan yang lebih tinggi diharapkan dapat memberikan manfaat dalam upaya meningkatkan disiplin kerja dan kinerja. ${ }^{8}$ Dengan demikian dapat diasumsikan bahwa pegawai yang memilik pendidikan lebih tinggi akan lebih mudah termotivasi, karena ia telah memiliki pengetahuan dan wawasan yang lebih luas, mampu memecahkan masalah lebih terampil, lebih cakap serta mempunyai sikap ke arah positif dibandingkan dengan pegawai yang berpendidikan lebih rendah yang akan berdampak terhadap peningkatan kinerja.

\section{Hubungan antara Status Perkawinan dengan Tingkat Disiplin Kerja Karyawan Rumah Sakit PTPN VIII Subang}

Status perkawinan responden pada penelitian ini terdapat $73,9 \%$ (17 responden) kawin dan terdapat 26,1\% (6 responden) berstatus tidak kawin. Berdasarkan hasil uji bivariat diperoleh hasil bahwa terdapat 10 responden $(58,8 \%)$ berstatus kawi yang mempunyai tingkat disiplin kerja yang kurang. Hasil uji statistik dengan chi square diperoleh $p$ value $=0,019$ dapa alpha 0,05 maka dapat disimpulkan bahwa hipotesis : ada hubungan yang signifikan antara status perkawinan responden dengan tingkat disiplin kerja karyawan Rumah Sakit PTPN VIII Subang tahun 2018 gagal ditolak.

Hasil penelitian ini tidak sesuai dengan pendapat bahwa status perkawinan berpengaruh terhadap perilaku seseorang dalam kehidupan organisasinya, baik secara positif maupun negatif. ${ }^{8}$. Karyawan menikah lebih sedikit absensinya, mengalami turn over yang lebih rendah dan lebih mengekspresikan perasaan puas terhadap pekerjaannya daripada yang belum menikah. Hal ini disebabkan karena adanya tanggung jawab terhadap pemenuhan kebutuhan ekonomi keluarga.

Hasil penelitian ini ada perbedaan dengan penelitian sebelumnya dimungkinkan karena banyaknya karyawan yang berstatus menikah di Rumah Sakit PTPN VIII Subang ini adalah berjenis kelamin perempuan (7 responden yang sudah menikah dari jumlah 11 responden perempuan), di mana perempuan lebih mempunyai kecenderungan mempunyai tingkat kemangkiran dan absensi yang lebih tinggi jika dibandingkan dengan jenis kelamin laki-laki. ${ }^{8}$

\section{Hubungan antara Masa Kerja dengan Tingkat Disiplin Kerja Karyawan Rumah Sakit PTPN VIII Subang}

Berdasarkan hasil uji univariat diperoleh hasil bahwa terdapat 43,5\% (10 responden) mempunyai masa kerja kurang dari 5 tahun dan terdapat 56,5\% (13 responden) mempunyai masa kerja lebih dari 5 tahun dan hasil uji bivariat diperoleh hasil bahwa terdapat 10 responden yang mempunyai masa kerja kurang dari 5 tahun dan 80,0\% mempunyai tingkat disiplin kerja yang kurang, dan terdapat 13 responden yang memiliki masa kerja lebih dari 5 tahun yang mempunyai tingkat disiplin kerja yang baik. Hasil uji statistik dengan chi square diperoleh $p$ value $=0,003$ dapa alpha 0,05 maka dapat disimpulkan bahwa hipotesis : ada hubungan yang signifikan antara masa 
kerja responden dengan tingkat disiplin kerja karyawan Rumah Sakit PTPN VIII Subang tahun 2018 gagal ditolak.

Hasil penelitian ini sesuai dengan yang menyatakan bahwa lama kerja berpengaruh terhadap pengalaman dan keterampilan dalam melakukan pekerjaannya. Karyawan yang telah berpengalaman akan lebih siap dan mampu menyelesaikan pekerjaannya dibandingkan yang belum berpengalaman, dengan demikian bahwa lama kerja individu dalam suatu profesi akan semakin meningkatkan kinerja dan produktivitasnya., ${ }^{4,8,11}$

Berdasarkan hasil penelitian dan beberapa pendapat di atas, peneliti berasumsi bahwa karakteristik individu yang melekat pada karyawan seluruhnya berhubungan dengan tingkat kedisiplinan kerjanya. Hal ini mengharuskan pihak manajemen puskesmas untuk terus memberikan motivasi kepada individu karyawan, baik motivasi berupa penghargaan secara material seperti pemberian jasa pelayanan maupun non finansial seperti kesempatan mengikuti pelatihan dan pendidikan berkelanjutan bagi karyawan yang berprestasi.

\section{SIMPULAN}

Karakteristik individu karyawan Rumah Sakit PTPN VIII Subang adalah sebagai berikut:

1. Karyawan Rumah Sakit PTPN VIII Subang 60,9\% berumur $25-45$ tahun

2. Karyawan Rumah Sakit PTPN VIII Subang 52,2\% berjenis kelamin laki-laki

3. Karyawan Rumah Sakit PTPN VIII Subang 52,2\% berpendidikan rendah

4. Karyawan Rumah Sakit PTPN VIII Subang 73,9\% berstatus kawin

5. Sebanyak $56,5 \%$ karyawan memiliki lama kerja lebih $\geq 5$ tahun.

6. Disiplin kerja karyawan Rumah Sakit PTPN VIII Subang 56,5\% mempunyai disiplin yang baik

7. Ada hubungan antara karakteristik individu dengan tingkat disiplin kerja karyawan Rumah Sakit PTPN VIII Subang

\section{SARAN}

\section{Bagi Pegawai}

Individu mempunyai karakteristik yang berbeda-beda antara yang satu dengan yang lainnya dan hasil ini menunjukkan adanya hubungan yang signifikan dengan tingkat disiplin kerja, sehingga dalam menerapkan disiplin kerja seperti membuat aturan dan kebijakan manajer harus memperhatikan karakteristik masing-masing karyawan yang menjadi tanggung jawabnya.

\section{Bagi Rumah Sakit PTPN VIII Subang}

Karakteristik individu mempunyai hubungan yang signifikan dengan tingkat disiplin kerja, sehingga institusi perlu memperhatikan karakteristik individu dalam upaya penciptaan kedisiplinan kerja bagi stafnya sehingga tercapai produktivitas kerja yang optimal.

\section{Bagi Peneliti Lain}

Penelitian ini hanya menghubungkan karakteristik individu dengan disiplin kerja, maka bagi peneliti lain dapat mencari faktor lain yang berhubungan dengan disiplin kerja karyawan rumah sakit.

\section{Bagi Institusi Pendidikan STIKes Cirebon}

Hasil penelitian ini menunjukkan ada hubungan antara karakteristik individu dengan disiplin kerja sehingga disarankan bagi pendidikan untuk dapat mengembangkan dan melakukan penelitian lain yang terkait dengan disiplin kerja dengan faktor lain selain karakteristik individu

\section{DAFTAR PUSTAKA}

1. Ilyas, Y. Kinerja: Teori, penilaian dan penelitian. Jakarta : Pusat Kajian Ekonomi Kesehatan FKM UI; 2007

2. Azwar,A. Menjaga mutu pelayanan kesehatan. Jakarta: Pustaka Sinar Harapan; 2006

3. Aditama, Y.T. Manajemen administrasi rumah sakit, Jakarta: Universitas Indonesia; 2005.

4. Hasibuan, S.P. Qrganisasi dan motivasi, Cetakan ke dua. Jakarta: Bumi Aksara; 2005 
5. Anastasia. Psikologi Industri Edisi ketujuh. Jakarta: Erlangga; 2006.

6. Gibson, Ivancevich, Donnelly. Organisasi: Struktur dan Proses, Edisi 8. Jilid 2. Jakarta: Binarupa Aksara; 2006.

7. Robbins, P.S. Perilaku Organisasi. Edisi Bahasa Indonesia, Edisi Kesepuluh, PT. Indek Jakarta; 2006.

8. Siagian. D.S. Manajemen Sumber Daya Manusia. Jakarta: Bumi Aksara; 2004.

9. Notoatmodjo, S. Pengembangan sumberdaya manusia. Jakarta : Rineka Cipta; 2005

10. Nursalam. Konsep dan Penerapan Metodologi Penelitian Ilmu Keperawatan. Jakarta: Salemba Medika; 2006

11. Hasibuan, S.P. Organisasi dan Motivasi, Cetakan ke Tujuh. Jakarta: Bumi Aksara; 2005

12. Timpe, D.A., Sari Manajemen Sumber Daya Manusia: Produktivitas. Edisi 5. Alih Bahasa: Dimas Samudra. Jakarta: PT Gramedia; 2006

13. Arikunto, S., Prosedur Penelitian: Suatu Pendekatan Praktek. Jakarta : Rineka Cipta;2007

14. Davis, K \& Newstorm, J.W. Perilaku dalam Organisasi. Edisi 7. Jakarta :Erlangga; 2008 